\title{
Keputusan Santri Dalam Membeli Di Online Shop: Antara Lifestyle, Trust Dan Price
}

\author{
Eri Shofa Rohmatul Umma, Moh. Nurul Qomar*, Jaenal Arifin \\ Fakultas Ekonomi dan Bisnis Islam, Institut Agama Islam Negeri Kudus. \\ Jalan Ngemba Bae Kudus, 59341, Indonesia
}

\begin{abstract}
This study aims to determine the influence of Lifestyle Trust and Prices on Purchasing Decisions in Onlineshop at Raudlatul Falah Islamic Boarding School Students in Pati Patis. This type of research is quantitative, with a total sample of 81 respondents. Data analysis techniques include validity test, reliability test, classic assumption test, multiple linear regression analysis, coefficient of determination, and ttest. The results of this study indicate that lifestyle and trust have a positive and significant effect, while price does not significantly influence purchasing decisions online at Raudlatul Falah boarding school students in Gembong Pati. With a lifestyle significance test of 0,000 with a t- count of 6. 374, a significance level of confidence of 0. 002 with a t-count of 2. 350, and a price significance level of- 0.786 with $t$ - count of- 0 . 273. It can be concluded that $\mathrm{H} 1$ and $\mathrm{H} 2$ in this study were accepted and H3 was rejected.
\end{abstract}

Keywords: Lifestyle, Trust, Price and Purchasing Decisions.

Paper type: Research paper

*Corresponding author: mnqomar@iainkudus.ac.id

Received: 23 Juli 2020, ; Accepted: 03 Oktober 2020; Published: Desember 2020

Cite this document: Umma, E.S.R., Qomar, M. N., \& Arifin, J. (2020). Keputusan Santri Dalam Membeli di Online Shop: Antara Lifestyle, Trust dan Price. BISEI: Jurnal Bisnis dan Ekonomi Islam, 5(2), 15-30.

Copyright (C) 2020, BISEI: JurnalBisnis dan Ekonomi Islam http://ejournal.unhasy.ac.id/index.php/bisei 
Abstrak: Riset ini bertujuan untuk mengenali pengaruh Lifestyle, Trust Serta Harga Terhadap Keputusan Pembelian Di Onlineshop Pada Santri Pondok Pesantren Raudlatul Falah Gembong Pati. Tipe riset ini merupakan kuantitatif, dengan jumlah ilustrasi sebanyak 81 responden. Metode analisis informasi meliputi uji validitas, uji reliabilitas, uji anggapan klasik, analisis regresi linier berganda, koefisien determinasi serta uji t. Hasil riset ini menampilkan kalau style hidup serta keyakinan mempengaruhi positif serta signifikan, sebaliknya harga tidak mempengaruhi signifikan terhadap keputusan pembelian di onlineshop pada santri pondok pesantren Raudlatul Falah Gembong Pati.Dengan uji signifikansi style hidup sebesar 0, 000 dengan thitung sebesar 6, 374, tingkatan signifikansi keyakinan sebesar 0, 002 dengan thitung sebesar 2, 350 serta tingkatan signifikasi harga sebesar- 0, 786 dengan thitung sebesar- 0, 273. Perihal ini bisa disimpulkan kalau H1 serta H2 dalam riset ini diterima serta H3 ditolak.

Kata kunci: Produktivitas, Ekonomi Islam, Jasmani, Rohani, Dunia, Akhirat

\section{Pendahuluan}

Pertumbuhan teknologi sangat mempengaruhi dalam merubah ikatan sosial kemasyarakatan disebabkan watak fleksibilitas serta keahlian telematika buat masuk ke aspek- aspek kehidupan warga (Noegroho, 2010). Salah satu teknologi yang sangat mempengaruhi merupakan internet. Bermacam wujud media baru bermunculan dengan basis teknologi internet, sehingga internet diucap dengan media baru (Halim, 2015). Media baru yang diartikan dalam bidang ekonomi merupakan website marketplace yang meningkat masing- masing tahunnya.

Jumlah pengguna internet di Indonesia hadapi pertumbuhan yang pesat tiap tahun. Bersumber pada informasi Asosiasi Penyelenggara Internet Indonesia, pengguna internet hadapi kenaikan semacam dibawah ini (APJII), 2018):

\section{Tabel 1.1}

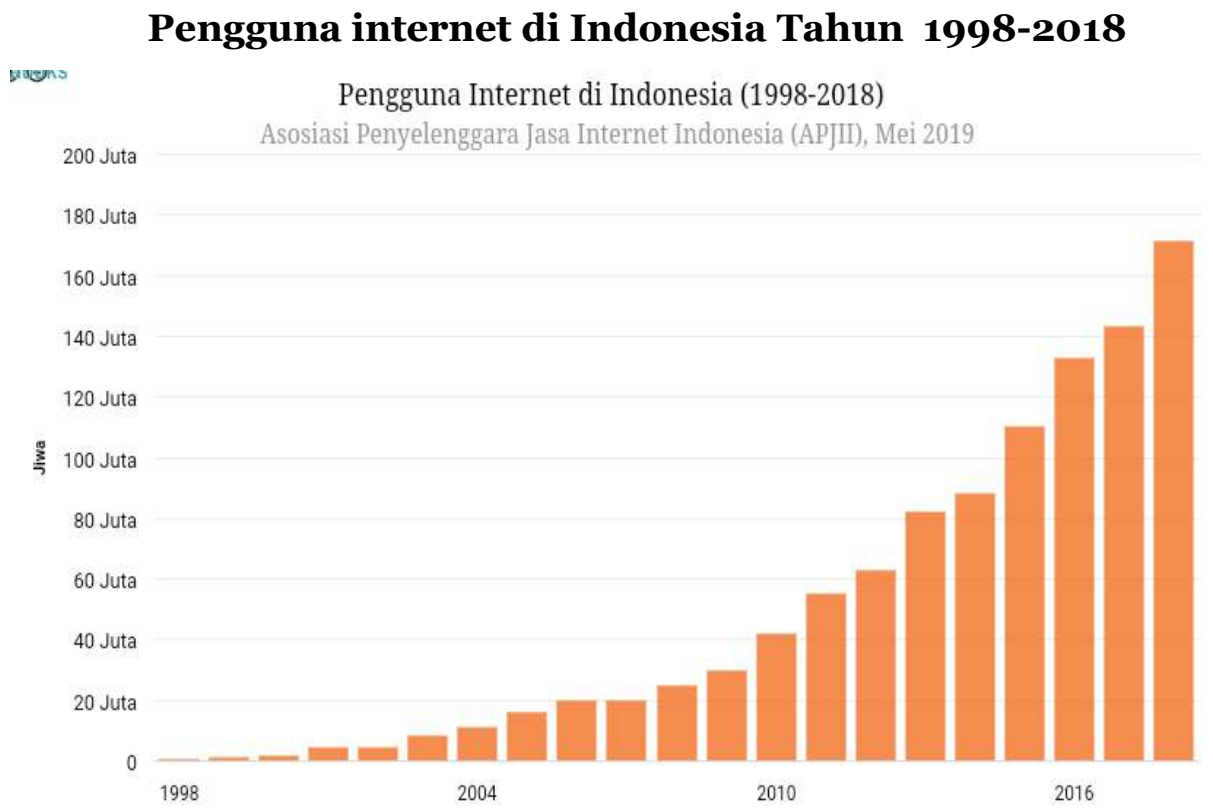

Sumber: Asosiasi Penyelenggara Jasa Internet Indonesia (APJII).

Copyright (C) 2020, BISEI: Jurnal Bisnis dan Ekonomi Islam http://ejournal.unhasy.ac.id/index.php/bisei 
Bersumber pada informasi di atas bagi hasil survei APJII serta Polling Indonesia jumlah pengguna internet di Indonesia pada tahun 2018 meningkat 27, 91 juta $(10,12 \%), 18$ juta jiwa. Maksudnya terjalin akumulasi pengguna internet ditanah air bertambah jadi 64, 8\% dari total penduduk yang menggapai 264, 16 juta jiwa. Sedangkan bersumber pada istimewa, Jawa masih jadi daerah pengguna internet terbanyak di Indonesia ialah menggapai 55\%. Ada pula pengguna internet terbanyak sehabis jawa merupakan Sumatera (21\%), Kalimantan (9\%), Sulawesi, Maluku serta Papua (10\%), dan Bali serta usa Tenggara sebanyak 5\%.

Sebagian industri e-commerce memakai teknologi internet buat mengembangakan e-bussines dengan memperkenalkan onlineshop yang sanggup diakses oleh segala pengguna internet di Indonesia. Menariknya merupakan santri pondok pesantren memiliki donasi bagaikan pembeli pada onlineshop tersebut. Dengan keadaan serta ketentuan pondok pesantren yang ketat serta menghalangi pemakaian hand phone (HP) buat tiap santrinya serta tidak memperbolehkan memakainya tidak hanya waktu yang sudah diresmikan oleh pondok pesantren ialah satu bulan satu kali pada dikala mereka dijenguk oleh orangtua, serta sanak saudaranya. Tetapi sebab pengaruh dari globalisasi serta modernisasi dalam bidang kemajuan teknologi yang sudah masuk dalam pondok pesantren menyebabkan para santri pula mempengaruhi memiliki sikap konsumtif buat membeli sesuatu produk ataupun benda lewat onlineshop. Walaupun waktu buat bawa HP telah diresmikan, tetapi senantiasa saja terdapat sebagian santri yang melaksanakan pembelian produk ataupun benda lewat onlineshop diluar waktu yang sudah diresmikan oleh pondok pesantren dalam mengakses internet, perihal itu dicoba dengan metode meminjam smartphone dari murobi.

Murobi merupakan orang yang ditugaskan disuatu lembaga buat membagikan ilmu pengetahuan kepada pelajar ataupun santri. Bila dipondok pesantren Raudlatul Falah tugas seseorang murobi meningkat tidak cuma bagaikan seseorang yang mengarahkan ilmu kepada pelajar ataupun santri, tetapi pula bagaikan orang yang mengurus kebutuhan pokok dari para santri, misalnya mempersiapkan santapan pada dikala jam makan, serta pula mengantarkan duit saku para santrinya. Umumnya satu orang murobi memiliki 10 hingga 15 santri.

Style hidup ialah salah satu penanda dari aspek individu yang ikut mempengaruhi terhadap sikap konsumen. Style hidup mencerminkan suatu dibalik kelas sosial seseorang orang serta menggambarkan gimana metode mereka mengahabiskan waktu serta uangnya (Oktari, 2016). bila seorang memiliki style hidup yang kelewatan dengan didasarkan oleh kemauan bukannya kebutuhan hingga dia hendak jadi seorang yang konsumtif.

Style hidup santri bisa berganti, hendak namun pergantian ini tidaklah didasarkan atas kebutuhan. Dikala tiba masa pubertas, kanak- kanak bukan lagi menjadikan orang tuanya bagaikan salah satunya panutan, melainkan orang- orang yang biasanya yang hendak jadi model utama (Dias, 2015). Dari bermacam media sosial para santri juga bisa dengan gampang menciptakan trend centernya entah dalam, santapan yang mau disantap, ataupun tempat yang mau didatangi, serta style berpakaiannya mulai dari pernak- pernik, jilbab, mode, tas sepatu serta yang lain bisa dipesan lewat media sosial. 
Buat menarik atensi konsumen buat berkunjung serta bertransaksi lewat situsnya, industri e- commerce wajib membangun keyakinan yang besar terhadap calon pembeli. Kala seorang mau melaksanakan transaksi secara online, hingga perihal utama yang dicermati merupakan reputasi online shop tersebut. Aspek yeng membentuk kepercayan seorang terhadap yang lain terdapat 3 ialah keahlian (ability), kebaikan hati (benevelonce), serta integritas (integrity) (Wong, 2017). Bila telah terdapat salah seseorang dari santri yang sempat belanja di salah satu online shop, serta merasa puas dengan mutu produk ataupun pelayanannya hingga dia hendak merekomendasikan sahabat santri yang lain buat membeli ditoko yang sama. Keyakinan antar sahabat yang sudah terjalin tadinya inilah yang mendesak para santri lain buat berbelanja secara online.

Bagi ajaran yang sudah dipelajari dipondok pesantren perilaku membeli benda yang tidak sangat dipentingkan ataupun diperlukan itu dikhawatirkan hendak memunculkan perbuatan yang percuma ataupun mubadzir. Sebaliknya mubadzir dalam bermacam aspek kehidupan itu sudah dilarang semacam dalam firman Allah SWT bagaikan berikut:

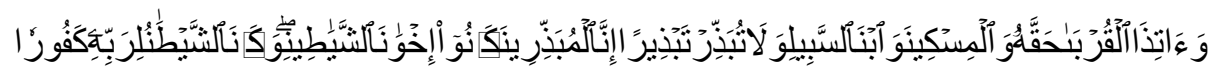

“ serta berikanlah kepada keluarga- keluarga yang dekat hendak haknya, kepada orang miskin serta orang yang dalam ekspedisi serta janganlah kalian menghambur- hamburkan (hartamu) secara boros. (26) Sebetulnya pemborospemboros itu merupakan saudara- saudara syaitan serta syaitan itu merupakan sangat ingkar kepada Tuhannya. (27)” (QS. Al- Isra' ayat 26- 27).

Ayat diatas menarangkan kalau Allah SWT membagikan penegasan kepada para umatNya dilarang buat menghambur- hamburkan harta yang kita miliki secara boros ataupun kelewatan. Dalam ayat tersebut pula Allah berfirman kalau orang- orang yang berperilaku boros serta berbuat mubadzir merupakan saudarasaudaranya setan sementara itu setan itu sangat ingkar kepada Tuhannya yaitu Allah SWT. Konsumen muslim yang taat, dirinya hendak menyadari kalau harta yan dimilikinya sepatutnya dibelanjakan buat kebutuhan individu serta buat dibelanjakan dijalan Allah (Rahmadi, 2015).

Berbeda dengan style hidup serta keyakinan, aspek harga pula jadi aspek yang berarti buat dicermati mengingat keadaan keuangan ataupun duit saku yang wajib bisa dikelola serta disiasati dengan baik supaya tidak hadapi defisit ataupun kehilangan duit saat sebelum orangtua membagikan duit saku berikutnya. Sebab bila tidak bisa mengelola duit saku dengan baik sebab uangnya dihabiskan buat komsumsi ataupun membeli benda yang tidak sangat diperlukan ataupun membeli benda buat penuhi keinginannya semata, perihal ini hendak menyebabkan santri tidak mempunyai duit, hingga dari itu harga dari sesuatu produk yang mau dibeli inilah wajib dipertimbangkan secara matang saat sebelum melaksanakan keputusan buat membeli sesuatu produk.

Keputusan pembelian absolut terletak ditangan para konsumen yang hendak melaksanakan belanja lewat internet. Ada sebagian aspek yang pengaruhi keputusan pembelian konsumen. Proses pengambilan keputusan dipengaruhi oleh 
aspek budaya, aspek sosial, aspek individu serta aspek psikologi (Kotler \& amp; Keller, 2016).

Sebagian riset masih berkutat tingkatan pengambilan keputusan pada tingkatan mahasiswa salah satu suatu universitas ataupun suatu outlet tertentu. Perihal itu cocok dengan riset Anis Purposari (2017) yang menarangkan kalau ada pengaruh keprcayaan serta harga terhadap keputusan pembelian. Riset lain yang dicoba oleh Sri Rahayu dkk (2015). Tetapi belum terdapat yang mengunakan objek riset di sebuah pondok pesantren. Hingga dari itu, penulis memakai pondok pesantren sebagai objek dalam penelitiannya. Objek dari riset ini merupakan Pondok Pesantren Raudlatul Falah Gembong Pati.

Dari waktu kewaktu guna pesantren terus berjalan serta tumbuh secara dinamis buat menjajaki pertumbuhan global di warga sosial. Pada awal mulanya lembaga ini berperan bagaikan lembaga sosial serta penyiaran agama islam. Hendak namun dalam perkembangannya hingga masa saat ini, pesantren pula menyelenggarakan pembelajaran resmi, baik yang berbentuk sekolah universal ataupun sekolah madrasah. Pesantren mempunyai batas dalam mengakses media massa tercantum internet. Tidak hanya buat menghindari pengaruh kurang baik internet terhadap santri pula diakibatkan waktu buat mengakses media serta internet sangat terbatas. Tetapi di sisi lain teknologi internet yang tumbuh secara kilat, diterapkan pada bermacam bidang kehidupan warga saat ini tercantum bidang pembelajaran (Sumilar, 2015).

Pada masa global pondok pesantren relatif telah banyak yang menggunakan internet diberbagai aspeknya. Pesantren tersebut tidak terbatas pada pesantren modern saja namun pesantren tradisional (salafiyah) pula (Anwas, 2015). Pesantren bagaikan salah satu lembaga pembelajaran susah buat menghindari masuknya teknologi kedalam ruang lingkup pesantren itu sendiri. Perihal ini meyakinkan kalau keberadaan internet untuk pelajar ataupun mahasiswa yang tinggal di pondok pesantren telah jadi kebutuhan sehari- hari yang tidak bisa dipisahkan dari style hidup warga dikala ini tidak terkecuali para santri spesialnya dalam riset ini merupakan golongan santri yang terletak di Pondok Pesantren Raudlatul Falah.

Disatu sisi pesantren wajib mempertahankan tradisi kepesantrenannya bagaikan lembaga asli ataupun indegenous Indonesia, namun disisi lain pesantren tidak dapat menjauh dari globalisasi serta modernisasi dengan seluruh produk yang ditawarkan. Dia menawarkan suatu pilihan yang ambivelen, satu sisimembawa kebaikan serta sisi lain bawa petaka apabila tidak siap menghadapinya (Syafe' i, 2017).

Pesantren merupakan lembaga pembelajaran yang mempunyai pangkal historis yang lumayan kokoh sehingga menduduki posisi relatif sentral dalam dunia keilmuan. Dalam masayarakatnya pesantren bagaikan sub kultul lahir serta tumbuh bersamaan dengan perubahan- perubahan dalam masyarakat global. Ditinjau dari segi historisnya, pesantren ialah wujud lembaga pribumi tertua di Indonesia. Lembaga pesantren telah diketahui jauh saat sebelum Indonesia merdeka, apalagi semenjak Islam masuk ke Indonesia, pesantren terus tumbuh cocok dengan pertumbuhan dunia pembelajaran pada biasanya (Bashori, 2017). 
Pondok Pesantren Raudlatul Falah ialah pondok pesantren yang mempunyai kebijakan lain untuk para santrinya buat mengakses internet. Ialah diresmikan tiap satu bulan sekali pada dikala santri dijenguk oleh para keluarganya, tidak hanya waktu yang sudah didetetapkan tersebut para santri juga tidak diperkenankan buat bawa HP serta mengakses smartphone. Perihal itu diharapkan para santri juga mempunyai bekal guna mengalami pertumbuhan teknologi dikala ini, serta pula tidak hanya momen tersebut aktivitas para santri diisi dengan bebagai modul mulai dari ilmu agama, hafalan Alqur' an, ilmu pengetahuan universal, sampai bergam ekstrakulikuler yang sudah diselenggarakan oleh Pondok Pesantren Raudlatul Falah tersebut. Keterbatasan dalam mengakses intenet tersebut ialah konsekuensi yang wajib diterima oleh seseorang santri. Hendak namun penjaga Pondok Pesantren Raudlatul Falah tidak menafikan berartinya internet dalam mendesak pengembangan keilmuan santri. Walaupun demikian, internet senantiasa wajib dikendalikan buat menghindari tergerusnya nilai- nilai keagamaan yang terdapat dalam diri santri.

\section{Metode Penelitian}

Penelitian ini termasuk jenis penelitian field reseacrh yaitu suatu penelitian yang dilakukan dengan turun langsung ke lapangan atau dilingkungan tertentu. Peneliti memilih santri pondok pesantren Raudlatul Falah Gembong Pati. Dalam penelitian ini peneliti menggunakan metode pendekatan kuantitatif untuk mengetahui hubungan variabel-variabel yang akan diteliti. Dengan menggunakan metode perhitungan statistik yang akan digunakan oleh peneliti sehingga memudahkan dalam menghitung data dari para santri Pondok Pesantren Raudaltul Falah Bermi Gembong Pati yang pernah melakukan pembelian melalui onlineshop.

Sampel yang digunakan dalam penelitian ini adalah santri pondok pesantren Raudlatul Falah Gembong Pati yang sudah pernah melakukan pembelian di onlineshopmeskipun hanya satu kali. Dalam penelitian ini pengambilan sampel anggota dilakukan dengan cara non probability sampling. Dimana Nonprobability sampling adalah teknik pengambilan sampel yang tidak memberi peluang atau kesempatan sama bagi setiap unsur atau anggota populasi untuk dipilih menjadi sampel. Teknik sampel ini meliputi, sampling sistematis, kuota, aksidental, purposive, jenuh, snowball.

\section{Hasil dan Pembahasan}

\section{Produktivitas Dalam Perspektif Ekonomi Islam}

Keberadaan Pondok Pesantren sebagai lembaga pendidikan Islam tertua di Indonesia, telah tumbuh dan berkembang sejak masa penyiaran Islam, dan telah banyak berperan dalam mencerdaskan kehidupan masyarakat yang ada di lingkungan pondok pesantren maupun luar daerah. Sejarah pondok pesantren menunjukkan bahwa lembaga ini tetap eksis dan konsisten menjalankan fungsinya sebagai pusat pengajaran ilmu-ilmu agama Islam (tafaqquh fiddin).

Seiring dengan perkembangan zaman, pendidikan di pondok pesantren juga mengalami pembaharuan dan pengembangan misalnya dalam hal kurikulum dan 
metode pembelajarannya. Sebagian pesantren telah mengakomodasikan progam pendidikan madrasah atau sekolah, dan sebagian lagi masih ada yang tetap mempertahankan pola pendidikan khas pesantren yang telah lama berlangsung.

Pondok pesantren Raudlatul Falah adalah salah satu pondok pesantren yang mengikuti pekembangan zaman dan memenuhi kebutuhan yang diperlukan oleh masyarakat sekitar. Pada tanggal 22 Mei 1988 (7 Syawal 1408) Bapak KH.Ahmad Djaelani beserta tokoh masyarakat didesa Bermi tersebut mengadakan pertemuan yang memutuskan bahwa para tokoh agama tersebut bersepakat untuk mendirikan pendidikan Madrasah Diniyah Awwaliyah. Dengan nama "RAUDLATUL ULUM".

Beriringan dengan semain pesatnya kemajuan pendidikan madrasah Raudlatul Ulum dan tambahnya jumlah santri, juga datangnya santri dar berbagai luar daerah yang bermukim dirumahnya Bapa KH Ahmad Djaelani, maka dengan kesepakatan bersama pada tanggal 6 Maret 1990 didirikanlah pondok pesantren. Yang mana pertama kali pondok yang di dirikan adalah pondok bagian putra (laki-laki). Dengan diberkahi Bapak KH Ulinnuha Arwani dari Kudus. Dan pondok tersebut diberi nama "MATHLA'UL FALAH" (Ponpes, 2019).

Pada tanggal 16 Agustus 1991 dengan beberapa pertimbangan antara ustadz dan pengurus supaya pondok dan madrasah selalu berkaitan, maka nama pondok dan madrasah di sempurnakan menjadi satu yaitu "RAUDLATUL FALAH". Dengan semakin bergabungnya pendidikan di Raudlatul Falah yang sama-sama berjalan dengan baik beberapa ustadz ingin mempererat dan saling menggabungkan antara bagian satu dengan lainny, maka pada tanggal 21 November 1994 terbentuklah suatu yayasan dengan nama "Yayasan Raudlatul Falah " dengan Akte Notaris No.43.11.94. Mengingat adanya tuntutan dari masyarakat dan juga melengkapi mutu pendidikan didalam lingkungan yayasan Raudlatul Falah untuk mengantisipasi arus era globalisasi supaya tidak mengelola pendidikan agama saja, maka pada tanggal 6 Mei 1996 didirikanlah SMP Islam dan SMA Islam.

\section{Karakteristik Responden}

Karakteristik responden menjelaskan mengenai identitas responden dalam penelitian ini, sebab dengan menjelaskan identitas responden yang menjadi sampel dalam penelitian ini maka akan dapat diketahui sejauh mana identitas responden. Responden yang menjadi sampel dalam penelitian ini adalah santri yang sudah pernah melakukan pembelian barang atau produk melalui onlineshop mekipun hanya satu kali dan oleh karena itu, karakteristik responden dalam penelitian ini meliputi jenis kelamin, umur, pengalaman pembelian, dan rekomendasi pembelian responden. Penjelasan berbagai karakteristik tersebut adalah sebagai berikut:

\section{a. Jenis Kelamin Responden}

Berdasarkan data penelitian yang dilakukan dengna penyebaran kuesioner maka diperoleh data tentang jenis kelamin responden pada tabel 4.2 sebagai berikut: 


\section{Diagram 4.1}

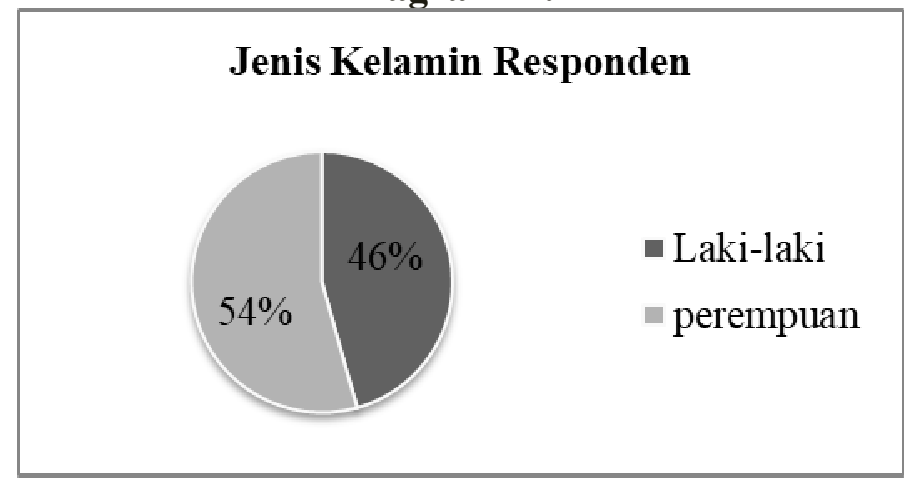

Sumber: data primer yang diolah, 2019

Berdasarkan Tabel 4.2 menunjukkan jenis kelamin yang melakukan pembelian melalui onlineshop adalah laki-laki sebanyak 37 orang atau 46\%, sedangkan perempuan sebanyak 44 orang atau $54 \%$.

\section{b. Umur Responden}

Berdasarkan data penelitian yang dilakukan dengan penyebaran kuesioner, maka dapat diperoleh data tentang umur responden pada tabel 4.3 sebagai berikut:

\section{Diagram 4.2}

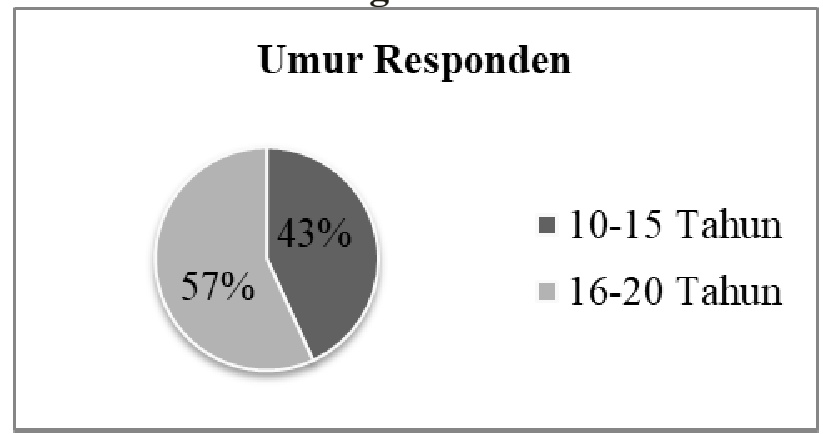

Sumber: data primer yang diolah, 2019

Berdasarkan Tabel 4.3 menunjukkan umur responden yang melakukan pembelian melalui onlineshop adalah 10-15 tahun sebanyak 35 orang atau 43\%, sedangkan 16-20 tahun sebanyak 46 orang atau 57\%.

\section{c. Pengalaman Pembelian Responden}

Berdasarkan data penelitian yang dilakukan dengan penyebaran kuesioner, maka dapat diperoleh data tentang pengalaman pembelian responden pada tabel 4.4 sebagai berikut: 
Diagram 4.3

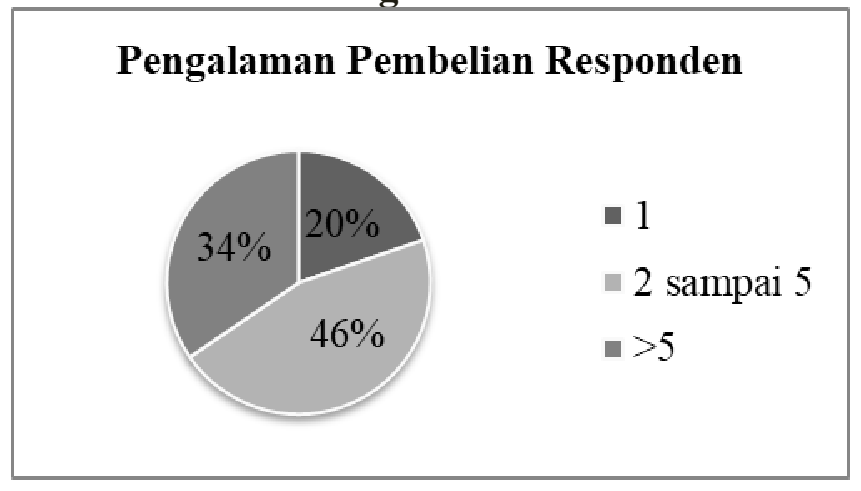

Sumber: data primer yang diolah, 2019

Berdasarkan Tabel 4.4 menunjukkan pengalaman pembelian responden yang melakukan pembelian melalui onlineshop adalah 1 kali sebanyak 16 orang atau 20\%, 2-5 kali sebanyak 37 orang atau $46 \%$ sedangkan $>5$ kali sebanyak 28 orang atau $34 \%$.

\section{d. Rekomendasi Pembelian Responden}

Berdasarkan data penelitian yang dilakukan dengan penyebaran kuesioner, maka dapat diperoleh data tentang rekomendasi pembelian responden pada tabel 4.5 sebagai berikut:

\section{Diagram 4.4}

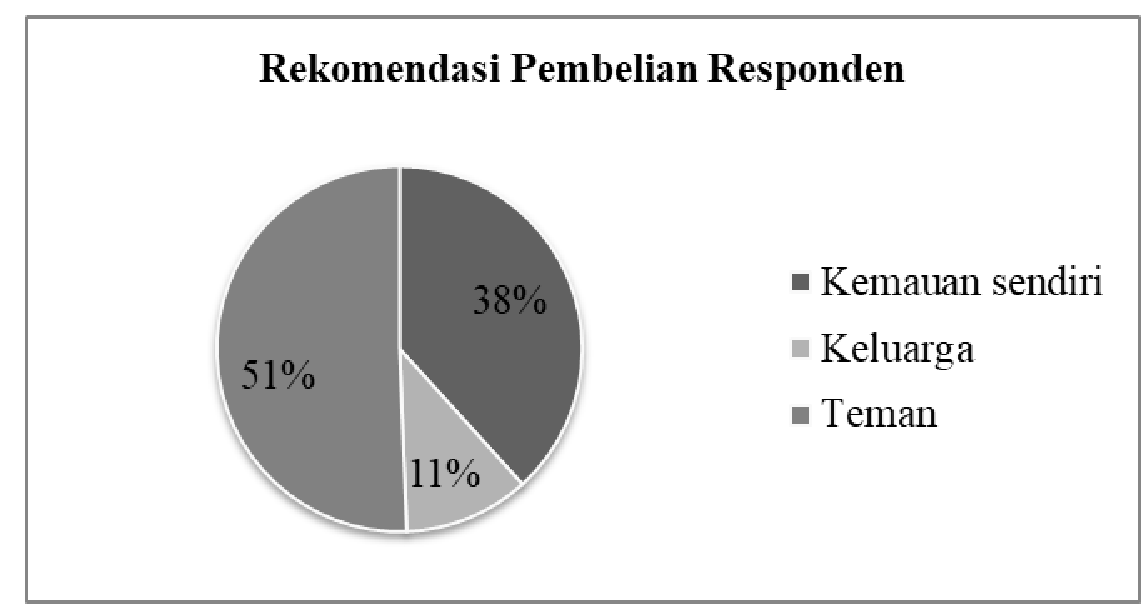

Sumber: data primer yang diolah, 2019

Berdasarkan Tabel 4.5 menunjukkan rekomendasi pembelian responden yang melakukan pembelian melalui onlineshop adalah kemauana sendiri sebanyak 31 orang atau 38\%, diikuti dari keluarga sebanyak 9 orang atau $11 \%$ sedangkan rekomendasi dari teman sebanyak 41 orang atau $51 \%$.

\section{Deskripsi Hasil Penelitian}


Hasil dari masing-masing jawaban responden tentang pengaruh gaya hidup, kepercayaan dan harga terhadap keputusan pembelian melalui onlineshop pada santri Pondok Pesantren Raudlatul Falah Gembong Pati adalah sebagai berikut:

\section{a. Variabel Gaya Hidup (X1)}

Pada variabel gaya hidup terdiri dari 5 (lima) item pernyataan dengan kuesioner sebanyak 81 responden. Hasil dari masing-masing jawaban responden tentang pengaruh gaya hidup adalah sebagai berikut:

\section{Tabel 4.2}

Hasil Penelitian Gaya Hidup (X1)

\begin{tabular}{|c|c|c|c|c|c|c|c|c|c|c|c|}
\hline Variabel & Item & SS & $\%$ & $\mathrm{~S}$ & $\%$ & $\mathrm{~N}$ & $\%$ & $\mathrm{TS}$ & $\%$ & STS & $\%$ \\
\hline \multirow{5}{*}{$\begin{array}{l}\text { Gaya } \\
\text { Hidup } \\
\text { (X1) }\end{array}$} & 1 & 13 & $16 \%$ & 33 & $\begin{array}{c}40,7 \\
\%\end{array}$ & 34 & $\begin{array}{l}42 \\
\%\end{array}$ & 1 & $\begin{array}{c}1,2 \\
\%\end{array}$ & 0 & $0 \%$ \\
\hline & 2 & 7 & $\begin{array}{c}8,6 \\
\%\end{array}$ & 46 & $\begin{array}{c}56,8 \\
\%\end{array}$ & 28 & $\begin{array}{l}34, \\
6 \%\end{array}$ & 0 & $0 \%$ & 0 & $0 \%$ \\
\hline & 3 & 8 & $\begin{array}{c}9,9 \\
\%\end{array}$ & 40 & $\begin{array}{c}49,4 \\
\%\end{array}$ & 28 & $\begin{array}{l}34, \\
6 \%\end{array}$ & 5 & $\begin{array}{c}6,2 \\
\%\end{array}$ & 0 & $0 \%$ \\
\hline & 4 & 10 & $\begin{array}{c}12,3 \\
\%\end{array}$ & 47 & $58 \%$ & 21 & $\begin{array}{l}25 \\
9 \%\end{array}$ & 2 & $\begin{array}{c}2,5 \\
\%\end{array}$ & 1 & $\begin{array}{l}1,2 \\
\%\end{array}$ \\
\hline & 5 & 0 & $0 \%$ & 32 & $\begin{array}{c}39,5 \\
\%\end{array}$ & 34 & $\begin{array}{l}42 \\
\%\end{array}$ & 2 & $\begin{array}{c}2,5 \\
\%\end{array}$ & 13 & $16 \%$ \\
\hline
\end{tabular}

Sumber: data primer yang diolah, 2019

Berdasarkan tabel di atas, data hasil angka untuk variabel Gaya hidup (X1) akan dijelaskan sebagai berikut:

1) Pada item gaya hidup hasil pertama,

Hasil dari penelitian pernyataan pertama yaitu menunjukan bahwa yang menyatakan sangat setuju sebanyak $16 \%$, setuju $40,7 \%$, memilih sikap netral sebanyak $42 \%$, dan tidak setuju sebanyak $1,2 \%$.

2) Pada item gaya hidup hasil kedua,

Hasil dari penelitian pernyataan kedua yaitu menunjukan bahwa yang menyatakan sangat setuju sebanyak $8,6 \%$, setuju $56,8 \%$, memilih sikap netral sebanyak $34,6 \%$.

3) Pada item gaya hidup hasil ketiga,

Hasil dari penelitian pernyataan ketiga yaitu menunjukan bahwa yang menyatakan sangat setuju sebanyak 9,9\%, setuju 49,4\%, memilih sikap netral sebanyak $34,6 \%$, dan tidak setuju sebanyak 6,2\%.

4) Pada item gaya hidup hasil keempat,

Hasil dari penelitian pernyataan keempat yaitu menunjukan bahwa yang menyatakan sangat setuju sebanyak $12,3 \%$, setuju $58 \%$, memilih sikap netral sebanyak $25,9 \%$, tidak setuju sebanyak $2,5 \%$ dan sangat tidak setuju sebanyak $1,2 \%$.

5) Pada item gaya hidup hasil kelima,

Hasil dari penelitian pernyataan kelima yaitu menunjukan bahwa yang menyatakan sangat setuju sebanyak $0 \%$, setuju $39,5 \%$, memilih 
sikap netral sebanyak $42 \%$, tidak setuju sebanyak $2,5 \%$, dan sangat tidak setuju sebesar $16 \%$.

\section{b. Variabel kepercayaan (X2)}

Pada variabel kepercayaan terdiri dari 3 (tiga) item pernyataan dengan kuesioner sebanyak 81 responden. Hasil dari masing-masing jawaban responden tentang pengaruh kepercayaan adalah sebagai berikut:

\section{Tabel 4.3}

Hasil Penelitian Kepercayaan (X2)

\begin{tabular}{|c|c|c|c|c|c|c|c|c|c|c|c|}
\hline Variabel & Item & SS & $\%$ & S & $\%$ & N & $\%$ & TS & $\%$ & STS & $\%$ \\
\hline $\begin{array}{c}\text { Keperca } \\
\text { yaan }\end{array}$ & 1 & 22 & $\begin{array}{c}27,2 \\
\%\end{array}$ & 52 & $\begin{array}{c}64,2 \\
\%\end{array}$ & 6 & $\begin{array}{c}7,4 \\
\%\end{array}$ & 1 & $\begin{array}{c}1,2 \\
\%\end{array}$ & 0 & $0 \%$ \\
\cline { 2 - 11 } & 2 & 29 & $\begin{array}{c}35,8 \\
\%\end{array}$ & 49 & $\begin{array}{c}60.5 \\
\%\end{array}$ & 3 & $\begin{array}{c}3,7 \\
\%\end{array}$ & 0 & $0 \%$ & 0 & $0 \%$ \\
\cline { 2 - 10 } & 3 & 29 & $\begin{array}{c}35,8 \\
\%\end{array}$ & 49 & $\begin{array}{c}60,5 \\
\%\end{array}$ & 3 & $\begin{array}{c}3,7 \\
\%\end{array}$ & 0 & $0 \%$ & 0 & $0 \%$ \\
\hline
\end{tabular}

Sumber: data primer yang diolah, 2019

Berdasarkan tabel di atas, data hasil angka untuk variabel Kepercayaan (X2) akan dijelaskan sebagai berikut:

1) Pada item kepercayaan hasil pertama,

Hasil dari penelitian pernyataan pertama yaitu menunjukan bahwa yang menyatakan sangat setuju sebanyak $27,2 \%$, setuju $64,2 \%$, memilih sikap netral sebanyak 7,4\%, dan tidak setuju sebanyak $1,2 \%$.

2) Pada item kepercayaan hasil kedua,

Hasil dari penelitian pernyataan kedua yaitu menunjukan bahwa yang menyatakan sangat setuju sebanyak $35,8 \%$, setuju $60,5 \%$, memilih sikap netral sebanyak3,7\%.

3) Pada item kepercayaan hasil ketiga,

Hasil dari penelitian pernyataan ketiga yaitu menunjukan bahwa yang menyatakan sangat sangat setuju sebanyak 35,8\%, setuju $60,5 \%$, memilih sikap netral sebanyak $3,7 \%$.

\section{c. Variabel harga (X3)}

Pada variabel harga terdiri dari 4 (empat) item pernyataan dengan kuesioner sebanyak 81 responden. Hasil dari masing-masing jawaban responden tentang pengaruh harga adalah sebagai berikut:

Tabel 4.4

Hasil Penelitian Harga (X3)

\begin{tabular}{|c|c|c|c|c|c|c|c|c|c|c|c|}
\hline Variabel & Item & SS & $\%$ & S & $\%$ & N & $\%$ & TS & $\%$ & STS & $\%$ \\
\hline $\begin{array}{c}\text { Harga } \\
(\mathrm{X} 3)\end{array}$ & 1 & 21 & $\begin{array}{c}25,9 \\
\%\end{array}$ & 50 & $\begin{array}{c}61,7 \\
\%\end{array}$ & 7 & $\begin{array}{c}8,6 \\
\%\end{array}$ & 3 & $\begin{array}{c}3,7 \\
\%\end{array}$ & 0 & $0 \%$ \\
\cline { 2 - 11 } & 2 & 21 & $\begin{array}{c}25,9 \\
\%\end{array}$ & 54 & $\begin{array}{c}66,7 \\
\%\end{array}$ & 6 & $\begin{array}{c}7,4 \\
\%\end{array}$ & 0 & $0 \%$ & 0 & $0 \%$ \\
\cline { 2 - 11 } & 3 & 18 & $\begin{array}{c}22,2 \\
\%\end{array}$ & 58 & $\begin{array}{c}71,6 \\
\%\end{array}$ & 4 & $\begin{array}{c}4,9 \\
\%\end{array}$ & 1 & $\begin{array}{c}1,2 \\
\%\end{array}$ & 0 & $0 \%$ \\
\hline
\end{tabular}




\begin{tabular}{|l|l|l|l|l|l|l|l|l|l|l|l|}
\hline & 4 & 25 & $\begin{array}{c}30,9 \\
\%\end{array}$ & 49 & $\begin{array}{c}60,5 \\
\%\end{array}$ & 6 & $\begin{array}{c}7,4 \\
\%\end{array}$ & 1 & $\begin{array}{c}1,2 \\
\%\end{array}$ & 0 & $0 \%$ \\
\hline
\end{tabular}

Sumber: data primer yang diolah, 2019

Berdasarkan tabel di atas, data hasil angka untuk variabel harga (X3) akan dijelaskan sebagai berikut:

1) Pada item harga hasil pertama,

Hasil dari penelitian pernyataan pertama yaitu menunjukan bahwa yang menyatakan sangat setuju sebanyak $25,9 \%$, setuju $61,7 \%$, memilih sikap netral sebanyak 8,6\%, dan tidak setuju sebanyak 3,7 \%.

2) Pada item harga hasil kedua,

Hasil dari penelitian pernyataan kedua yaitu menunjukan bahwa yang menyatakan sangat setuju sebanyak $25,9 \%$, setuju $66,7 \%$, memilih sikap netral sebanyak $7,4 \%$.

3) Pada item harga hasil ketiga,

Hasil dari penelitian pernyataan ketiga yaitu menunjukan bahwa yang menyatakan sangat setuju sebanyak $22,2 \%$, setuju $71,6 \%$, memilih sikap netral sebanyak 4,9\%, dan tidak setuju sebanyak $1,2 \%$.

4) Pada item harga hasil keempat,

Hasil dari penelitian keempat yaitu menunjukan bahwa yang menyatakan sangat setuju sebanyak $30,9 \%$, setuju $60,5 \%$, memilih sikap netral sebanyak $7,4 \%$, dan tidak setuju sebanyak $1,2 \%$.

\section{d. Variabel Keputusan Pembelian (Y)}

Pada variabel keputusan pembelian terdiri dari 5 (lima) item pernyataan dengan kuesioner sebanyak 81 responden. Hasil dari masing-masing jawaban responden tentang keputusan pembelian adalah sebagai berikut:

Tabel 4.5

Hasil Penelitian Keputusan Pembelian (Y)

\begin{tabular}{|c|c|c|c|c|c|c|c|c|c|c|c|}
\hline Variabel & Item & SS & $\%$ & $\mathrm{~S}$ & $\%$ & $\mathrm{~N}$ & $\%$ & $\mathrm{TS}$ & $\%$ & $\begin{array}{c}\text { ST } \\
\text { S }\end{array}$ & $\%$ \\
\hline \multirow{5}{*}{$\begin{array}{c}\text { Keputusan } \\
\text { Pembelian } \\
\text { (Y) }\end{array}$} & 1 & 11 & $\begin{array}{c}13,6 \\
\%\end{array}$ & $\begin{array}{l}4 \\
1\end{array}$ & $\begin{array}{c}50,6 \\
\%\end{array}$ & $\begin{array}{l}2 \\
8\end{array}$ & $\begin{array}{c}34,6 \\
\%\end{array}$ & 1 & $\begin{array}{c}1,2 \\
\%\end{array}$ & 0 & $0 \%$ \\
\hline & 2 & 12 & $\begin{array}{c}14,8 \\
\%\end{array}$ & $\begin{array}{l}4 \\
5\end{array}$ & $\begin{array}{c}55,6 \\
\%\end{array}$ & $\begin{array}{l}2 \\
3 \\
\end{array}$ & $\begin{array}{c}28,4 \\
\%\end{array}$ & 1 & $\begin{array}{c}1,2 \\
\%\end{array}$ & 0 & $0 \%$ \\
\hline & 3 & 8 & $\begin{array}{c}9,9 \\
\%\end{array}$ & $\begin{array}{l}4 \\
0\end{array}$ & $\begin{array}{c}49,4 \\
\%\end{array}$ & $\begin{array}{l}2 \\
8\end{array}$ & $\begin{array}{c}34,6 \\
\%\end{array}$ & 5 & $\begin{array}{c}6,2 \\
\%\end{array}$ & 0 & $0 \%$ \\
\hline & 4 & 14 & $\begin{array}{c}17,3 \\
\% \\
\end{array}$ & $\begin{array}{l}4 \\
5 \\
\end{array}$ & $\begin{array}{c}55,6 \\
\% \\
\end{array}$ & $\begin{array}{l}2 \\
1 \\
\end{array}$ & $\begin{array}{c}25,9 \\
\% \\
\end{array}$ & 1 & $\begin{array}{c}1,2 \\
\% \\
\end{array}$ & 0 & $0 \%$ \\
\hline & 5 & 9 & $\begin{array}{c}11,1 \\
\%\end{array}$ & $\begin{array}{l}4 \\
5\end{array}$ & $\begin{array}{c}55,6 \\
\%\end{array}$ & $\begin{array}{l}2 \\
5\end{array}$ & $\begin{array}{c}30,9 \\
\%\end{array}$ & 2 & $\begin{array}{c}2,5 \\
\%\end{array}$ & 0 & $0 \%$ \\
\hline
\end{tabular}

Sumber: data primer yang diolah, 2019

Berdasarkan tabel di atas, data hasil angka untuk variabel keputusan pembelian (Y) akan dijelaskan sebagai berikut:

1) Pada item keputusan pembelian hasil pertama, 
Hasil dari penelitian pernyataan pertama yaitu menunjukan bahwa yang menyatakan sangat setuju sebanyak $13,6 \%$, setuju $50,6 \%$, memilih sikap netral sebanyak 34,6\%, dan tidak setuju sebanyak1,2\%.

2) Pada item keputusan pembelian hasil kedua,

Hasil dari penelitian pernyataan kedua yaitu menunjukan bahwa yang menyatakan sangat setuju sebanyak $14,8 \%$, setuju $55,6 \%$, memilih sikap netral sebanyak $28,4 \%$, dan tidak setuju sebanyak $1,2 \%$.

3) Pada item keputusan pembelian hasil ketiga,

Hasil dari penelitian pernyataan ketiga yaitu menunjukan bahwa yang menyatakan sangat setuju sebanyak $9,9 \%$, setuju $49,4 \%$, memilih sikap netral sebanyak $34,6 \%$, dan tidak setuju sebanyak $6,2 \%$.

4) Pada item keputusan pembelian hasil keempat,

Hasil dari penelitian pernyataan keempat yaitu menunjukan bahwa yang menyatakan sangat setuju sebanyak $17,3 \%$, setuju $55,6 \%$, memilih sikap netral sebanyak $25,9 \%$, dan tidak setuju sebanyak $1,2 \%$.

5) Pada item keputusan pembelian hasil kelima,

Hasil dari penelitian pernyataan kelima yaitu menunjukan bahwa yang menyatakan sangat setuju sebanyak $11,1 \%$, setuju $55,6 \%$, memilih sikap netral sebanyak 30,9\%, dan tidak setuju sebanyak $2,5 \%$.

\section{Pembahasan Hasil Penelitian}

\section{a. Pengaruh Gaya Hidup (X1) Terhadap Keputusan Pembelian Di} Onlineshop Pada Santri Raudlatul Falah

Berdasarkan hasil pengujian yang telah dilakukan menunjukkan nilai koefisien regresi yang bernilai positif yaitu 0,620 yang berarti bahwa gaya hidup mempunyai hubungan positif terhadap keputusan pembelian. Hal ini sejalan dengan teori yang dikemukakan Philip Kotler yang mengatakan bahwa faktor gaya hidup dipengaruhi oleh perilaku pembelian yang diartikan sebagai sebuah pola hidup seseorang dalam aktifitas, minat dan opininya yang terbentuk melalui berbagai kelas sosial dan pekerjaan.

Selain itu juga dibuktikan dari hipotesis yang ternyata hasil $t_{\text {hitung }}$ sebesar 6,374 dan nilai tabel 1,994 maka nilai thitung $>t_{\text {tabel. }}$ Adapun nilai signifikasinya yaitu $0,000<0,05$. Hasil tersebut menunjukkan bahwa variabel gaya hidup memberikan pengaruh positif terhadap keputusan pembelian. Dengan demikian hipotesis pertama (H1) diterima, yang berarti bahwa terdapat pengaruh yang signifikan gaya hidup akan meningkatakan keputusan pembelian di onlineshop pada santri pondok pesantren Raudlatul Falah Gembong Pati. Hasil penelitian menunjukkan bahwa gaya hidup berpengaruh positif signifikan terhadap keputusan pembelian di onlineshop.

\section{b. Pengaruh Kepercayaan (X2) Terhadap Keputusan Pembelian Di Onlineshop Pada Santri Raudlatul Falah}

Dari hasil koefisien regresi dikatakan besarnya parameter koefisien regresi untuk variabel kepercayaan (X2) sebesar 0,430. Hal ini menyatakan bahwa setiap terjadi kenaikan faktor kepercayaan akan 
meningkatkan keputusan pembelian di onlineshop pada santri Raudlatul Falah. Selain itu juga dibuktikan dari hasil hipotesis yang ternyata nilai thitung lebih besar dari tabel $(2,350>1,994)$ maka artinya hipotesis kedua $\left(\mathrm{H}_{2}\right)$ diterima. Sehingga dapat disimpulkan bahwa terdapat pengaruh yang

signifikan kepercayaan terhadap keputusan pembelian di onlineshop pada santri Raudlatul Falah Gembong Pati. Kepercayaan merupakan kunci untuk membangun suatu hubungan baik jangka menengah maupun jangka panjang. Hasil penelitian menunjukkan bahwa kepercayaan berpengaruh positif signifikan terhadap keputusan pembelian.

\section{c. Pengaruh Harga (X3) Terhadap Keputusan Pembelian Di Onlineshop Pada Santri Raudlatul Falah}

Hasil koefisien regresi dikatakan besarnya parameter koefisien regresi untuk variabel harga (X3) sebesar -0,040. Hal ini menyatakan bahwa setiap terjadi kenaikan faktor harga akan mengurangi keputusan pembelian di onlineshop tanpa dipengaruhi oleh faktor lain. Hal ini mengidentifikasikan bahwa harga yang diberikan kepada konsumen tidak mempengaruhi keputusan pembelian.

Harga tidak berpengaruh signifikan terhada keputusan pembelian di onlineshop pada santri Raudlatul Falah Gembong Pati, dapat disimpulkan bahwa banyak santri yang menilai harga produk atau barang yang ditawarkan dionlineshop belum tentu lebih murah pada pada toko biasa (bukan online), ada santri yang merasa harga produk terkadang tidak sesuai dengan kualitas produk yang ditampilkan ditoko online. Sehingga santri mencari tahu perbandingan harga produl offline dan produk online. Memang ada beberapa toko online yang harganya memang lebih murah jika dibandingkan dengan toko offline, namun harga produk tersebut belum termasuk ongkos kirim kekota konsumen sehingga terkadang hargamya bisa jadi lebih mahal daripada toko offline. Diskon atau potongan harga yang diberikan juga belum tentu membuat konsumen langsung mau dengan produk yang ada, kalau tidak diimbangi dengan produk yang baik kualitasnya. Apalagi santri di Radlatul Falah ini disini cenderung menyukai produk yang murah tetapi mempunyai kualitas produk yang bagus.

Selain itu, dibuktikan dengan nilai thitung lebih kecil dari tabel ($0,025<1,994)$ maka hipotesis ketiga $(\mathrm{H} 3)$ ditolak. Dan dapat dinyatakan bahwa tidak terdapat pengaruh dan tidak signifikan antara harga terhadap keputusan pembelian di onlineshop pada santri Raudlatul Falah Gembong Pati. Hasil penelitian ini mendapatkan bahwa harga tidak berpengaruh dan tidak signifikan terhadap keputusan pembelian. 


\section{Penutup}

Penelitian ini bertujuan untuk mengetahui pengaruh gaya hidup, kepercayaan dan harga terhadap keputusan pembelian di onlineshop pada santri Raudlatul Falah Gembong Pati, maka dari hasil analisa dan pembahasan diatas dapat ditarik kesimpulan bahwa:

Pertama, Gaya hidup $\left(\mathrm{X}_{1}\right)$ mempunyai pengaruh yang signifikan terhadap keputusan pembelian (Y). Dapat diketahui dari hasil uji parsial ( $\mathrm{t}_{\text {hitung }}$ ) yang telah dilakukan pada masing-masing variabel diperoleh thitung pada variabel gaya hidup $\left(\mathrm{X}_{1}\right)$ sebesar 6,374 dengan nilai $t_{\text {tabel }}$ 1,994 ini berarti nilai $t_{\text {hitung }}$ lebih besar dari pada $t_{\text {tabel }}$ $(6,374>1,994)$ dengan nilai signifikan $0,000<0,05$ maka H1 diterima (terdapat pengaruh yang signifikan), yang artinya gaya hidup merupakan variabel bebas yang benar-benar mempengaruhi secara signifikan terhadap keputusan pembelian di onlineshop pada santri Raudlatul Falah Gembong Pati. Kedua, Kepercayaan $\left(\mathrm{X}_{2}\right)$ mempunyai pengaruh yang signifikan terhadap keputusan pembelian (Y). Dapat diketahui dari hasil uji parsial ( $\mathrm{t}_{\text {hitung }}$ ) yang telah dilakukan pada masing-masing variabel diperoleh $t_{\text {hitung }}$ pada variabel kepercayaan $\left(\mathrm{X}_{2}\right)$ sebesar 2,350 dengan nilai tabel 1,994 ini berarti nilai $t_{\text {hitung }}$ lebih besar dari pada tabel $(2,350>1,994)$ dengan nilai signifikan $0,021<0,05$, maka $\mathrm{H} 2$ diterima (terdapat pengaruh yang signifikan), yang artinya kepercayaan merupakan variabel bebas yang benar-benar mempengaruhi secara signifikan terhadap keputusan pembelian di onlineshop pada santri Raudlatul Falah Gembong Pati. Ketiga, Harga $\left(\mathrm{X}_{3}\right)$ tidak mempunyai pengaruh dan tidak signifikan terhadap keputusan pembelian (Y). Dapat diketahui dari hasil uji parsial ( $\mathrm{t}_{\text {hitung }}$ ) yang telah dilakukan pada masing-masing variabel diperoleh $t_{\text {hitung }}$ pada variabel harga $\left(\mathrm{X}_{3}\right)$ sebesar $-0,273$ dengan nilai $\mathrm{t}_{\text {tabel }} 1,994$ ini berarti nilai $t_{\text {hitung }}$ lebih kecil dari pada $t_{\text {tabel }}(-0,273<1,994)$ dengan nilai signifikan $0,786>0,05$, maka H3 ditolak (terdapat pengaruh yang tidak signifikan), yang artinya harga merupakan variabel bebas yang tidak berpengaruh dan tidak signifikan terhadap keputusan pembelian di onlineshop pada santri Raudlatul Falah Gembong Pati.

\section{Referensi \\ Buku}

Kotler, P., \& Keller, L. K. (2016). Manajemen Pemasaran. Erlangga.

Noegroho, A. (2010). Teknologi Komunikasi. Graha Ilmu.

\section{Jurnal}

Anwas, O. M. (2015). Pemanfaatan Teknologi Informasi Dan Komunikasi Pada Pesantren Rakyat Sumber Pucung Malang,. Jurnal Pendidikan Dan Kebudayaan, 21(3).

Bashori. (2017). Modernisasi Lembaga Pendidikan Pesantren. Jurnal Ilmu Soaial Mamangan, 6(1).

Dias, K. (2015). Pengaruh Literasi Ekonomi dan Gaya Hidup terhadap Gaya Hidup Konsumtif Mahasiswa Jurusan Pendidikan Ekonomi Undiksha. Jurnal Pendidikan EKonomi Undiksha, 5(1). 
Halim, N. A. (2015). Penggunaan Media Internet Dikalangan Remaja Untuk Mengembangkan Pemahaman Keislaman. Jurnal Risalah, 26(3).

Oktari, A. D. (2016). Hubungan Antara Gaya Hidup Konsumtif Dengan Keputusan Pembelian Pada Toko Perhiasan Dikawasan BanjarmasinBanjarbaru-Martapura Title. Jurnal Online Psikologi, 1(2).

Purposari, A. (2017). Pengaruh Kulaitas Layanan Kepercayaan Dan Harga Terhadap Keputusan Pembelian Online Produk Busana Melalui Media Sosial Instagram Dikalagan Mahasiswa Fakultas Ekonomi Dan Bisnis Islam IAIN Surakarta. Institut Agama Islam Negeri Surakarta.

Rahayu, S., Zuhriyah, \& Bonita, S. (2015). Pengaruh Gaya Hidup Dan Persepsi Mahasiswa Terhadap Keputusan Pembelian Secara Online Dikota Palembang. Jurnal Manajemen Dan Bisnis Sriwijaya, 13(3).

Rahmadi, I. (2015). Pengaruh Gaya Hidup Konsumen Muslim Terhadap Adopsi Smartphone Apple (Studi Pada Mahasiswa Fakultas Ekonomi Dan Bisnis Universitas Airlangga). JESTT, 2(3).

Sumilar, G. (2015). Pemanfaatan Internet Oleh Santri Pesantren Modern (Islamic Boardig School). https://repository.unikom.ac.id/30691/1/pemanfaataninternet-oleh-santripesantren-modern-gumgum-gumilar.pdf

Syafe'i, I. (2017). Pondok Pesantren: Lembaga Pendidikan Lembaga Karakter. AlTadzkiyah: Jurnal Pendidikan Islam, 8(1).

Wong, D. (2017). Pengaruh Ability, Benevolence, Dan Integrity Terhadap Trust, Serta Implikasinya Terhadap Partisipasi Pelanggan E-Commerce. Jurnal Riset Manajemen Dan Bisnis(JRMB), 2(2).

Web

(APJII), A. P. J. I. I. (2018). Data Pengguna Internet di Indonesia. http://www.apji.or.id/content/read/39/410/Hasil-Survei-Penetrasi-danPerilaku-Pengguna-Internet-Indonesia-2018

Dokumen Pondok Pesantren

Ponpes, T. R. F. (2019). Dokumentasi Tentang Sejarah Pondok Pesantren Raudatul Falah (pp. 1-23). 